\title{
Does Capital Punishment Amount to Cruel, Inhuman and Degrading Punishment: A Reflection on Botswana and South Africa
}

\author{
Nico P. Swartz ${ }^{1}$ \\ ${ }^{1}$ Department of Law, University of Botswana ,Gaborone, Botswana \\ Correspondence: Nico P. Swartz, Department of Law, University of Botswana, Private Bag 00705. Gaborone, \\ Botswana. Tel: 267-355-2373. E-mail: nico.swartz@mopipi.ub.bw
}

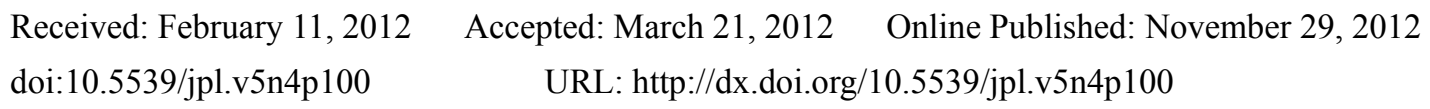

\begin{abstract}
In a recent debate over the radio in Botswana on the death penalty, the majority of callers seemed to be in favour of the death penalty. The purpose of this paper is to clarify that capital punishment is cruel, inhuman and degrading contrary to the norms set out in the Convention against Torture, the optional protocol to the United Nations Covenant on Civil and Political Rights (ICCPR) on the abolition of the death penalty. The methodology of this paper is to invoke the South African sentiment and international treaties to buttress the notion that death penalty amounts to the taking of a human life and is tantamount to the infringement of basic human right to life as enshrined in both the Botswana and the South African Constitution. South Africa heeded to this call and abolished capital punishment, whereas Botswana not only includes capital punishment in its constitution, but couched this form of punishment in a mandatory fashion. In the Botswana case of Ntesang $v$ State however, the decision of execution by hanging attests to the cruelty and inhumanity of capital punishment. Under the influence of international treaties and conventions the particular judge in this case invited the state to outlaw the death penalty. The judge warned though, that the judiciary cannot rewrite the Constitution. The legislature can do it as it is the arm of government vested with law making powers. In order to materialize such a venture, Botswana must also take into account international treaties and conventions in the interpretation of its domestic legislation. Although Botswana does that, as seen in the light of section 24 of the Interpretations Act and the Unity Dow-case, it is done in a cursorily fashion. For this reason, Botswana has also to consider the South African stand on the death penalty. South African case law is not binding but merely persuasive. The South African position is the most appropriate model of comparison, seeing from the fact that capital punishment was also exerted during the apart-regime. The subsequent abolishment of capital under the new regime must served as a harbinger for Botswana to follow in the footsteps of its neigbour (South Africa).
\end{abstract}

Keywords: right to life, death penalty, mandatory sentence, ideology for life, cruel, inhuman and degrading treatment

\section{Introduction}

\subsection{Mandatory Nature of Capital Punishment}

A constitution limits the power of the government in two ways. First, it imposes structural and procedural limitations on the exercise of power and secondly, only through the operation of a Bill of Rights, may substantive limitations be imposed. The latter notion, which is of more concern to this research, entails that the state may not use its power in such a way as to violate any of a list of fundamental human rights of its citizenry and that it has a corresponding duty to use its power to protect and promote these rights.

This rule is articulated in section 11 of the South African Constitution, Act 108 of 1996 that everyone has the right to life. By committing itself to a society founded on the recognition of human rights South Africans are required to value the right to life above all others. Entrenchment of the right to life enables the state to take a leading role in re-establishing respect for human life. It means that the state should even refuse to destroy the life of criminals (Note 1).

The South African notion on the death penalty stands diametrically in opposition to the Botswana view on the death penalty. Botswana imposed a mandatory nature of the death sentence in section 204 of its Penal Code. A mandatory death sentence amounts to an arbitrary deprivation of life sanctioned by the state. Section 7(f) of the Resolution 2005/59 of the United Nations Commission on Human Rights urges states that the death penalty is not 
to be imposed as a mandatory sentence. Mr. Philip Alston, the United Nations Special Rapporteur on Extrajudicial, Summary or Arbitrary Executions concluded in his report to the United Nations Commission on Human Rights that "The mandatory death penalty ... precludes the possibility of a lesser sentence being imposed..." (Note 2).

The mandatory nature of the death sentence hinges upon mitigating factors or extenuating circumstances. Extenuating circumstances are: "Facts bearing on the commission of the crime, which reduces the moral blameworthiness of the accused as distinct from his or her culpability." (Note 4). A legal test to determine extenuating circumstances shall be the following: (i) Whether there were at the time of the commission of the crime facts or circumstances which could have influenced the accused's state of mind or mental faculties and could serve to constitute extension; (ii) Whether such facts or circumstances, in their cumulative effect, probably did influence the accused's state of mind in doing what he or she did; and (iii) Whether this influence was of such a nature as to reduce what he did." (Note 5).

These guidelines serve, on the one hand, as conduits for judges in Botswana to exercise their power to take into account extenuating circumstances (Note 6). Seeing from the conservative nature of the Botswana bench and the number of executions to date, this paper reasons to the contrary that the Botswana courts do sincerely fathom the guidelines as stipulated above. The former president F.G. Mogae lamented the fact that the courts were reluctant to impose the death penalty despite the fact that they were empowered to impose the same in the absence of extenuating circumstances.

In paying heed to these extenuating circumstances, judges will be able to remove the mandatory aspect from the sentencing for all capital offences. On the other hand, if Botswana is to ratify the Optional Protocol to the UN Convention against Torture and other Cruel, Inhuman or Degrading Treatment or Punishment, it will be able to remove mandatory death sentences gradually but surely.

Botswana Courts are in terms of section 24 of the Interpretation Act (of Botswana) been required to rely on any relevant international convention in the interpretation of domestic legislation.

\subsection{Research Objectives}

The paper provides a way for a possible abolition of the death sentence or penalty. The paper opted for an exploratory study using the open-ended approach theory, and the article draws on or demonstrate knowledge of the latest research-based literature on the topic. The latest Botswana cases, such as Ntesang and Kobedi, which dealt with the death penalty in the country are being treated in this study. The research may lack generalisability in that it is confined to the Africa continent. Cursory references are made to international treaties, but it is just to muster alliance for the abolition of the death penalty. The finding of the research holds that the death penalty is an inhuman punishment.

\section{Evolution from an Archaic Era to a Modern Democracy vis-à-vis Capital Punishment}

Capital punishment was tolerated as a necessary tool for an archaic age that was still blind to consequences of a society (Note 16). It must never be viewed as a permanent solution to the problem of violent crime. It is because it is retributive and the current trend is to move towards restorative justice. More so, because retribution has dismally failed to eliminate or even reduce the occurrence of murder in our society.

The $12^{\text {th }}$ century judge was limited in his options of punishment. Without sophisticated prison systems or reliable judicial apparatus, there was no conceivable solution to the problem of repeated offenders (Note 17). There were no police networks to actively protect against marauding bands of outlaws, nor was there a prison system to ensure the safe isolation of dangerous individuals. (Note 18).

Fortunately, these conditions simply do not exist today. We can protect society without killing its worst offenders. Capital punishment is therefore no longer an utopian expectation (Note 19).

We have the means and opportunity to isolate a dangerous criminal in such a way as to never place society in danger again. Escape is rare and virtually unknown in the highest security prisons. The police network of modern societies is so advanced that even if a criminal does escape, he will have to voluntarily remove himself from society, if he is to avoid recapture. It simply is no longer necessary to kill someone in order to provide society with sufficient protection against direct attack in future (Note 20).

In the $20^{\text {th }}$ century, we believe that each individual is entitled to the basic rights to life, liberty and property and that government exist in order to protect those rights.

Now that criminals and offenders can be dealt within means short of execution, we must seek to do so. In demanding the criminal's life when his removal from society is sufficient reflects an earthly pursuit of 
vengeance.

\section{Respect for Life: A South African Sentiment}

Governments must respect individual's basic fundamental human right, the right to life. This right is to be protected by law (Note 23).

In $S v$ Makwanyane 1995 (3) SA 391 (CC), which dealt with the constitutionality or not of the death penalty, the Constitutional Court of South Africa described the rights to life as the most important of all human rights. Langa $\mathrm{J}$ asserts in the particular case in paragraph 217: "the right to (and respect for) life is the most fundamental of all rights, the supreme human right." By committing ourselves to a society founded on the recognition of human rights we are required to value this right above all others (Note 24). The right to life is linked to a person's right to dignity which is inherent. Respect for life can also be linked to the African philosophical concept of ubuntu. The dominant theme of ubuntu undergirds the notion that the life of another person is as valuable as one's own (Note 25).

The South African sentiment about the death penalty is forwarded by Chaskalson J, who rejected an argument that those convicted of murder have forfeited their right to life. Chaskalson J says: "Constitutional rights vest in every person, including criminals convicted of vile crimes. Such criminals do not forfeit their rights under the Constitution and are entitled, as all in our country now are, to assert these rights, including the right to life..." (Note 28)

Chaskalson $\mathrm{J}$ held in the Makwanyane-case that the death penalty, which is an infringement of the right to and respect for life, a cruel, inhuman and degrading punishment. Other members of the court also found that the death penalty violated the right to and respect for life (Note 29).

On the strength of these observations, the death penalty remains therefore an unconstitutional form of punishment in the South African context.

\section{The State as Protector and Enforcer for the Right to Life}

The Constitutional Court held, in the Makwanyane-case (supra), that whether one sees the death sentence as forming part of the state's duty to protect life or not, it remains a form of punishment which needs to conform with the Bill of Rights and in particular, with the prohibition of cruel, inhuman or degrading forms of punishment (Note 30).

In Mohamed v President of the Republic of South Africa 2001 (3) SA 893 (CC), the court inclined states not to extradite individuals to jurisdictions where they may face the death penalty. In this case no assurance had been sought from the US authorities that Mohamed would not be subject to the death penalty if he was to be removed to the United States. This can be regarded as a violation of the state's duty to protect the right to life: "The removal of Mohamed to the United States could not have been effected without the co-operation of the South African immigration authorities. They co-operated well knowing that he would be put on trial in the United States and faces capital charges. They must also have known that there was a real risk that he would be convicted, and that unless an assurance to the contrary were obtained, he would be sentenced to death. In doing so they infringed Mohamed's rights under the Constitution and acted contrary to their obligations to uphold and promote the rights entrenched in the Bill of Rights." (Note 31). The court declared the conduct of the officials and the subsequent removal of the prisoner therefore unconstitutional and illegal. Their acts had violated the right of the prisoner to life and the protection against cruel, inhuman and degrading punishment.

In the cited case of Mohamed, Khalfan Mohamed had been indicted for alleged involvement in the bombing of US embassies in Kenya and Tanzania and on his arrival in New York he was charged with various offences related to bombing and informed by the court that the death penalty could be imposed on him if he was convicted. The South African government authorities use the impasse of the Mohamed-case in the extradition of people who commit murder in Botswana and then flee to South Africa. South Africa is reluctant to extradite unless the receiving country makes an undertaking not to execute the accused person in the event he is found guilty.

\section{Cruel, Inhuman and Degrading Treatment and Punishment}

Capital punishment amounts to cruel, inhuman and degrading punishment on four primary grounds. Firstly, because of the cruelty that inevitably flows from the indeterminable delays styled the death row syndrome, which convicted individuals face when awaiting execution and often the nature of the execution itself (Note 36). Secondly, the court has taken into account the irremediable nature of the punishment (Note 37). Thirdly, the failure of the sentence to treat the guilty person as a human being worthy of respect (Note 38). And finally, the 
almost inherent arbitrariness in the imposition of the death sentence (Note 39).

With regard to the first ground, the delay to which death row prisoners are subjected to for a long period of time is being regarded as inhumane and degrading and therefore unconstitutional (Note 40). In the Botswana court of appeal case of Lehlohonolo Kobedi v State (Criminal app 25 of 2001) 2003 BWCA 22 (19 March 2003), it is stated that, by the time he reaches his final appeal, the appellant had been on death row for 56 months. It can be contended that the death penalty is unconstitutional as it contravenes Section 7 of the Botswana Constitution, which deals with the protection from inhuman and degrading treatment. His (Kobedi's) execution after a long detention on death row would amount to an inhuman and degrading punishment (Note 41). On the basis hereof, the Court of Appeal in Botswana, has considered that the death row phenomenon could render the execution of the death penalty unconstitutional. In the Kobedi-case, the court accepted that this possibility existed and that the prohibition of inhuman or degrading punishment could be violated in such circumstances.

In 1993 the constitutional position regarding delay in carrying out the execution was considered by the Zimbabwe Supreme Court in Catholic Commission for Justice and Peace in Zimbabwe v Attorney-General SC 73/93 (Unreported). It was reported in a national newspaper that four condemned murderers were to be executed shortly. Sentenced between 1987 and 1988, their appeals were not dismissed by the Supreme Court until 1991. The court considered whether by March 1993 the dehumanizing factor of prolonged delay, viewed in conjunction with the harsh and degrading conditions in the condemned section of the holding prison, meant that the executions themselves would have constituted inhuman and degrading treatment contrary to Section 15(1) of the Constitution of Zimbabwe. In approaching its task, the court adopted a progressive and enlightened approach towards the plight of the condemned men noting that: "Prison walls do not keep out fundamental rights and protection and no matter the magnitude of the crime, prisoners are not reduced to non-persons but retain all basic rights, save those inevitably removed from them by law, expressly or by implication." (Note 42)

Lords Scarman and Brightman expressed a similar view in Riley v Attorney-General of Jamaica 19823 All ER 469 , that the jurisprudence of the civilized world "has recognized and acknowledged that prolonged delay in executing a sentence of death can make the punishment inhuman and degrading." A sentence of death is one thing, but sentence of death followed by lengthy imprisonment prior to execution is another. It is therefore inhuman to keep a man facing the agony of execution over a long extended period of time (Note 43).

Terblanche states that if the offender was subjected to inhumane conditions or treatment in prison, such facts would count in his favour (Note 44). This view is buttressed by the case of Catholic Commission for Justice and Peace in Zimbabwe $v$ Attorney-General, where the effect of the case was that death sentences on twenty other condemned prisoners who had endured lengthy periods on death row were commuted to life imprisonment (Note 45). This decision has received support from the Constitutional Court in South Africa (Note 46).

In terms of the second ground of cruel and inhuman treatment, it is to be noted that the act of executing someone is irrevocable. The risk of executing an innocent person is too high. Sun Wanhuai contends that it is better to run the risk of irregularity and error than to put an innocent person to death. In other words, if we are to maintain justice and purity of law, sparing the death penalty and letting someone who may be guilty goes free is better than applying it and executing someone who is innocent (Note 47).

The third ground refers to the arbitrary nature of the imposition of the death penalty. Given the vast majority of persons charged with capital offences, many will not be able to afford the services of advocates. In the interest of justice, an accused person should be entitled to be represented by an advocate of his choice at public expense. The question that can be posed, is whether such a person would receive satisfactory representation. For example, in Botswana the fees paid to pro deo counsel are minimal compared to average fees paid to private lawyers. The average fee paid to lawyers, for example in Botswana, is P450 per hour and P3000 per court attendance, compared to the P300 per court attendance in pro bono matters. Pro deo counsel is also not paid by the hour. The low fees to handle such cases explain reluctance of a number of experienced senior attorneys to take capital cases even when designated to do so by the Registrar of the High Court. The result is that most pro deo cases are handled by inexperienced lawyers who lack the skills, resources and commitment to handle such serious matters and this not only affects the rights of the accused but violates the same. The result would invariably be a miscarriage of justice, because the poor level of legal representation can lead to an unfair trial when young lawyers do not know how to handle death penalty cases and do not have the sufficient funds to locate potential witnesses and travel in order to take their statements. This situation violates the right to a fair trial enshrined in Articles 14 of the ICCPR (United Nations Covenant on Civil and Political Rights). According to International Federation for Human Rights: Kobedi was represented in his original hearing by a lawyer who was unfamiliar with trying death penalty cases, who failed to raise important legal and factual issues on his behalf (Note 48). 
Evidence suggests, as in the Kobedi-case, that in general, attorneys on pro deo briefs are noted neither for their caliber nor for their commitment. Hatchard \& Coldham buttress this notion, when they wrote, "In Tanzania, in a case where the constitutionality of the death penalty was raised, the trial judge pointed out that the risk of executing the innocent is increased by the fact that "'most poor persons do not obtain good legal representation, as they are defended by lawyers on dock briefs who are paid only T Shilings 500 (the equivalent of US \$1)" (49). The study stresses, on the one hand, that the availability of proper legal aid would help in safeguarding the interest of the accused person. On the other hand, the research connotes that more need to be done for the accused person. In South Africa, for example, the pro deo system has came under severe criticism. It is said that without effective representation, an accused can barely be said to have had a fair trial (Note 53).

Erroneous convictions and the fact that most poor defendants did not receive adequate legal representation, made capital punishment, cruel, inhuman and degrading (Note 54). Research has revealed that two thirds of death sentences are eventually overturned on appeal (Note 55). On the strength hereof, if the chances of wrongful conviction resulting in a death sentence were one in 100, some 20 per cent of those at present who are in favour of the death penalty would withdraw their support (Note 56).

\section{Method of Execution}

Section 26(1) of the Botswana Penal Code states: "When any person is sentenced to death, the sentence shall direct that he shall be hanged by the neck until he is dead."

The method of execution by hanging is a violation of Section 7(1) of the ICCPR. This convention asserts that hanging amounts to torture and inhuman and or degrading punishment. In Botswana case law, State $v$ Ntesang 1995 L.R.C. (Const) 338, although the decision that the execution by hanging was upheld, the judge acknowledged that death by hanging may be considered as torture, inhuman or degrading punishment or treatment. The judge took note of the international trend towards the abolition of the death penalty, invited the state to consider outlawing it: "... I have no doubt in my mind that the court has no power to re-write the Constitution in order to give effect to what the appellant has described as progressive movements taking place all over the world, and to give effect to the resolutions of the United Nations as to the abolition of the death penalty. I, however, express the hope that before long the matter will engage the attention of that arm of the government which has responsibility of effecting changes to the statutes for its consideration and changes which it may consider necessary to further establish the claim of this country as one of the great liberal democracies of the world." (Note 57).

The same way of thought as in the Ntesang-case (supra), is being reflected in the Botswana case of Mosarwa v the State 1985 B.L.R. 258. The Court of Appeal said (in the latter case), while there was international sentiment, as reflected at the United Nations, to abolish the death penalty, it could not re-write the Constitution in order to give effect to such sentiment. Section 7 of the Botswana Constitution states that if the punishment of death is imposed by a court of competent jurisdiction then such ruling must and should be upheld. The Botswana Court of Appeal insinuates that its function in the interpretation of the Constitution is rather adjudicatory and not legislative (Note 58). The Court alludes that it is the legislative arm of government that is tasked with the re-writing of the Constitution.

\section{Failure in Giving Timely Notice of Execution}

Pursuant to Section 18 of the Prisons Act of Botswana, the condemned prisoner in the Ping-case, is given notice of his execution at least 24 hours before the hanging. This procedure may itself amount to a violation of Articles 7 and 10(1) of the ICCPR as it may cause psychological or mental torture (Note 60).

The lawyers and the prisoner's family are neither informed of the execution that is going to take place. In fact, the lawyer(s) and the family are not authorized to see the prisoner before his execution. "Ms Alice Mogwe, the Director of Ditshwanelo, explained ... the day before the execution of Mr. Ping, she accompanied his mother to visit him. The prison authorities denied them access to the prisoner and asked his mother to return on Monday as it was not possible for her to see him at the time." (Note 61)

According to Mogwe, the prison officers were aware of the death warrant, but failed to tell the prisoner's mother that the execution had been scheduled the following day. Mr. Ping's family and his lawyer eventually heard about the execution over the radio (Note 62).

The failure to inform the family of the date of execution and the refusal to give the family access to the prisoner may result in inhuman and degrading treatment or punishment for both the prisoner and trauma to his or her family. The fact that the prisoner's family is not authorized to even see his grave, would also amount to inhuman and degrading treatment as this tends to be traumatic (Note 63). 
The United Nations Human Rights Committee concludes that the failure to inform the family of the date, the hour, the place of the execution of the prisoner as well as the exact place of the burial violate Article 7 of the $I C C P R$. These issues have the effect of intimidating or punishing families by intentionally leaving them in a state of uncertainty and mental distress. The conduct of the prison authorities amounts to inhuman and degrading treatment and by their conduct they fail to respect the human dignity of both the family and the prisoner and violate Articles 7 and 10(1) of the ICCPR.

On the basis of this analysis, it is submitted that the death penalty is cruel, inhuman and degrading (Note 64).

\section{Contribution of Appellate Court/ Courts in the Possible Abolition of the Death Sentence}

An appeal court can set aside a death sentence if it considers that it would not itself have imposed such a sentence and can impose the sentence which it considers appropriate (Note 66).

The Court of Appeal in Botswana has repeatedly acknowledged the cruel, inhuman and degrading nature of the death sentence. Because of this move, one can hope that the Courts of Botswana and especially the Court of Appeal may play a leading role towards the abolition of capital sentence (as an inhuman, degrading and cruel treatment) (Note 67).

This is an inclination for the abolition of the death penalty in Botswana. For example, in The case of Ntesang a judge make note of international trends towards the abolition of the death penalty and invited the state to consider outlawing it. In the same case, it was held that although, the decision that execution by hanging was upheld, a judge acknowledges that death by hanging may be considered as torture, inhuman or degrading.

In Zimbabwe, the then Chief Justice, Mr. Enoch Dumbutshena, publicly called for the abolition of the death penalty. This had some impact, because no executions took place after 1988 and in 1990 the government announced a moratorium on executions (Note 68).

Chaskalson CJ found in the Constitutional Court case of $S v$ Makwanyane 1995 (3) SA 391 (CC) that there was no proof that the death sentence was indeed a greater deterrent than imprisonment. He quoted police statistics at the time of the decision that in the previous five years an average 20000 murderers were committed and 9000 murder cases brought to trail. Only 243 death sentences were imposed and 142 of these being confirmed on appeal. He therefore posed the question: Would the carrying out of the death sentence on the 243 persons have deterred the other murders or saved any lives? (Note 69)

\section{Conclusions}

This paper holds the view that the death penalty to be an inhuman punishment, no matter how heinous the crime. The occurrence of a lesser sentence would by necessary implication be heralded with happiness.

States who uphold the death penalty must change their rhetoric to embrace the feeling that we ought never to requite wrong with wrong. It must not use its power in such a way as to violate any list of fundamental rights. Entrenchment of the right to life requires states to re-establish respect for human life. Many states, like South Africa, refuse to extradite individuals if they will be subjected to capital punishment in those countries they are to be extradited to. Universal acceptance and secure protection of the right to life of every person is the most important good that a society can bestow upon its members. It is entirely righteous that the state acts as final steward of all rights.

Botswana's imposition of a mandatory death sentence for crimes punishable by death, amounts to deprivation of life and is also contrary to international human rights instruments. Mandatory death penalty is also inconsistent with the prohibition of cruel, inhuman or degrading punishment. If Botswana is to adopt the conditions set by international treaties and conventions to become a signatory state, it will stand a chance to remove the mandatory death sentence that cause its infamy in the international arena. In today's world, abolition of the death penalty has become a general historical trend. (Note 70)

The modern liberal commandment to be "tolerant" and not to impose the majority's values on the minority has brought us to an ethical gridlock; we are unwilling to publicly declare and recommend the basics of human decency which we all know to be true and which most of us live by daily, and which we in fact consider normative.

\section{References}

Bayertz, K. (1996). Sanctity of Life and Human Dignity. Dordrecht: Kluwer Academic Publishers. http://dx.doi.org/10.1007/978-94-009-1590-9

Currie, I., \& de Waal, J. (2005). The Bill of Rights Handbook. In Association with Lawyers for Human Rights 
and the Law Society of South Africa (5th ed.). Cape Town: Juta \& Co. Ltd. Lansdown.

Hatchard, J. (1994). Capital Punishment in Southern Africa: Some Recent Developments. The International and Comparative Law Quaterly, 43(4), 923-934. http://dx.doi.org/10.1093/iclqaj/43.4.923

Hodgkinson, P., \& Rutherford, A. (1996). Capital Punishment. Global Issues and Prospects. Winchester: Waterside Press.

Hood, R. (2001). Capital Punishment: A Global Perspective. Punishment and Society, 3(3), 331-354.

International Federation for Human Rights. (2007). Retrieved from http://www.ditshwanelo.org.bw/index/current_issues/death_penalty/death\%20penalty520press\%20stat ement $\% 20-\% 2018 \% 20$ july\%202003.htm

International Federation for Human Rights. (2007). Ditshwanelo - The Botswana Centre for Human Rights. The Death Penalty in Botswana: Hasty and Secretive Hangings. International Fact-finding Mission.

Luban, D. (2007). Legal Ethics and Human Dignity. Cambridge Studies in Philosophy and Law. Cambridge: Cambridge University Press. http://dx.doi.org/10.1017/CBO9780511487484

Neff, S. C. (1984). Human Rights in Africa: Thoughts on the African Charter on Human and People's Rights in the Light of Case Law from Botswana, Lesotho and Swaziland. The International and Comparative Law Quarterly, 33(2), 331-347. http://dx.doi.org/10.1093/iclqaj/33.2.331

Philip, A. (2004). Rapport of the Special Rapporteur. Retrieved from http://www.ohchr.org/english/issues/executions/annual.htm.

Short, C. A. (1999). The Abolition of the Death Penalty: Does "Abolition" Really Means What You Think it Means? Indiana Journal of Global Legal Studies, 6(2), 721-756.

Singer, P. (1995). Rethinking Life and Death. The Collapse of Our Traditional Ethics. Great Britain: Oxford University Press.

Stetson, B. (1995). Human Dignity and Contemporary Liberalism. Praeger: Greenwood Publishing Group.

Streib, V. (2008). Death Penalty in a Nutshell (3rd ed.). USA: West A Thompson Business.

Terblanche, S. S. (2001). Sentencing murder and the Ideal of Equality. CILSA (pp. 97-122).

Wallace, D. H., \& Sorensen, J. R. (1997). Comparative Proportionality Review: A Nationwide Examination of Reversed Death Sentences. American Journal of Criminal Justice, 22(11), 13-40. http://dx.doi.org/10.1007/BF02887339

Wanhuai, S. (2009). Examining the Death Penalty in China. Abolishing the Death Penalty: The Logical Necessity of the Irrationality of the Death Penalty. Social Sciences in China, 30(2), 166-177. http://dx.doi.org/10.1080/02529200902903917

Zorea, A. W. (2000). In the Image of God. A Christian Response to Capital Punishment. Maryland: University Press of America.

\section{Court Cases}

Catholic Commission for Justice and Peace in Zimbabwe v Attorney-General SC 73/93 (Unreported).

Kaunda $v$ President of the Republic of South Africa 2004 (10) BCLR 1009 (CC).

Lehlonolo Kobedi $v$ State (Criminal app 25 of 2000) 2003 BWCA 22 (19 March 2003).

Mohamed $v$ President of the Republic of South Africa 2001 (3) SA 893 (CC).

Mosarwa v The State 1985 B.L.R. 258.

Ntamo v Minister of Safety and Security 2001 (1) SA 830 (Tk).

Ping $v$ (Crim App 045 of 2005) 2006 BWHC 8 (26 January 2006).

Riley v Attorney-General of Jamaica 19823 All ER 469.

Sv Dlamini 1991 (2) SACR 655 (A).

$S v$ Ferreira 2004 (2) SACR 454 (SCA).

Sv Letsolo 1970 (3) SA 476 (A).

Sv Maimela 1976 (2) SA 587 (A). 
Sv Makwanyane 1995 (3) SA 391 (CC).

Sv Malgas 2001 (1) SACR 469 (SCA).

S v Ntesang 1995 (4) BCLR 426 (Botswana).

State v Ntesang 1995 L.R.C. (Const) 338.

Sv Pietersen 1973 (1) SA 148 (A).

$S v$ Selemale 1994 (1) SACR 481 (A).

$S v$ Thebus 2002 (2) SACR 566 (SCA).

$S v V 1972$ (3) SA 611 (A).

Acts

Criminal Procedure Act 55 of 1977.

Criminal Law Amendment Act 105 of 1997.

Interim Constitution (1994).

Interpretation Act

Malawi Traditional Courts Act of 1969.

Nigerian Robbery and Firearms Decree of 1984.

The Constitution of South Africa, Act 108 of 1996.

\section{International Human Rights Instruments}

United Nations Special Rapporteur on Extrajudicial, Summary or Arbitrary Executions

United Nations Commission on Human Rights

International Federation for Human Rights

African Commission on Human and Peoples' Rights

Optional Protocol to the UN Convention against Torture and other Cruel, Inhuman or Degrading Treatment or Punishment

UN Convention Against Torture

UN Economic and Social Council

UN Commission on Human Rights; International Covenant on Civil and Political Rights (ICCPR)

The Convention against Torture and Other Cruel, Inhuman or Degrading Treatment or Punishment

\section{Notes}

Note 1. Currie \& de Waal (2005) 281.

Note 2. See E/CN.4/2005/7, 22 December 2004. Rapport of the Special Rapporteur, Philip Alston accessed at http://www.ohchr.org/english/issues/executions/annual.htm.

Note 3. International Federation for Human Rights (2007) 22.

Note 4. International Federation for Human Rights (2007) 23.

Note 5. International Federation for Human Rights (2007) 23.

Note 6. In Ntesang v $S 1995$ BLR 151 (CA), N made certain allegations regarding the business of the deceased, who instituted legal proceedings against him. When $\mathrm{N}$ could not afford an attorney to defend him, he lost the case and later received notice of attachment of his house. In reaction $\mathrm{N}$ obtained a gun, two bullets and balaclavas, and went to the deceased's compound at night where he eventually shot and killed him. The trial court found that the murder was premeditated: "He had planned to murder the deceased without detection...," with a "diabolic design." The Court of Appeal agreed, based on authority, that any emotional distress that N might have suffered as a result of his legal predicament could not be accepted as an extenuating circumstance. In Ping v S (Crim App 045 of 2005) 2006 BWHC 8 (26 January 2006), a mother and her child were found dead in her yard. Both had their throats cut with such force that their windpipes and the muscles at the front of the necks had been severed. $\mathrm{P}$ was convicted of these murders based on circumstantial evidence. For murdering the mother, 
he was convicted of murder with extenuating circumstances and sentenced to fifteen years' imprisonment. The extenuating circumstances were found in P's evidence that he had been stabbed by the mother before he killed her. However, in the case of the child there were no extenuating circumstances and $\mathrm{P}$ was sentenced to death. The Court of Appeal stressed that extenuating circumstances had to be found on the available evidence, and could not be based on speculation. P had denied any knowledge of the murders and provided no motive. The child had been killed in a gruesome manner, without any provocation. The appeal was dismissed.

Note 7. Zorea In the image of God (2000) xviii.

Note 8. Zorea (2000) xviii.

Note 9. Deut 24: 17; Exod 21; 12. Zorea (2000) xviii.

Note 10. Exod 21: 23-25; Deut 19: 21; Zorea (2000) xviii.

Note 11. Exod 21: 15, 17.

Note 12. Matt 5: 38-39; Luke 6: 29; Zorea (2000) xix.

Note 13. Matt 5: 43-44.

Note 14. John 8: 7.

Note 15. Zorea (2000) xxi.

Note 16. Zorea (2000) 222.

Note 17. Zorea (2000) 223.

Note 18. Zorea (2000) 198.

Note 19. Zorea (2000) 223.

Note 20. Zorea (2000) 198.

Note 21. Zorea (2000) 193.

Note 22. International instruments like: UN Convention Against Torture; UN Economic and Social Council; UN Special Rapporteur on Extrajudicial, Summary and Arbitrary Executions; UN Commission on Human Rights; International Covenant on Civil and Political Rights (ICCPR); The Convention against Torture and Other Cruel, Inhuman or Degrading Treatment or Punishment.

Note 23. Currie \& de Waal (2005) 29

Note 24. Currie \& de Waal (2005) 281.

Note 25. S v Makwanyane, para 225. See also para 308 (Mokgoro J).

Currie \& de Waal (20050 281.

Note 26. Sv Makwanyane, para 85.

Note 27. Currie \& de Waal (2005) 283.

Note 28. Sv Makwanyane, para 137.

Note 29. $S$ v Makwanyane, para 166 (Ackermann J); para 174 (Didcott J); paras 208, 214 (Kriegler J); paras 217, 234 (Langa J); para 268 (Mahomed J); para 313 (Mokgoro J); paras 318, 344 (O’Regan J); paras 350, 357 (Sachs J).

Note 30. Currie \& de Waal (2005) 285.

Note 31. Mohamed v President of the Republic of South Africa, para 60.

Note 32. Kaunda $v$ President of the Republic of South Africa, para 50.

Note 33. Kaunda $v$ President of the Republic of South Africa, para 255.

Note 34. Currie \& de Waal (2005) 287.

Note 35. The Interim Constitution was formally adopted as an Act of the pre-democratic Tricameral Parliament, ensuring the legal continuity of the South African state. After the 1994 elections, the new Parliament and a Government of National Unity were established and began to function in accordance with the Interim Constitution, which came into force on 27 April 1994. The Interim Constitution was a transitional constitution. One of its principal purposes was to set out the procedures for the negotiation and drafting of a "final" Constitution. Once the 19969 final) Constitution was adopted the Interim Constitution was repealed and fell 
away. But, in spite of its transitional status, the Interim Constitution was nevertheless binding, supreme and fully justiciable. It contained, in Chapter 3, a comprehensive Bill of Rights. Because the Interim Bill of Rights was for the most part similar to that in the 1996 Constitution, most of the judicial decisions on rights handed down under the Interim Constitution remain authoritative.

Note 36. Sv Makwanyane, paras 177-179.

Note 37. $S v$ Makwanyane, paras 54-56, 95, 196, 273-274, 351.

Note 38. $S v$ Makwanyane, paras 57-79.

Note 39. Chaskalson CJ, stated the following in $S v$ Makwanyane, para 94: "Proportionality is an ingredient to be taken into account in deciding whether a penalty is cruel, inhuman or degrading. No Court would today uphold the constitutionality of a statute that makes the death sentence a competent sentence for the cutting down of trees or the killing of deer, which were capital offences in England in the $18^{\text {th }}$ century.

Note 40. International Federation for Human Rights 2007: 21.

Note 41. International Federation for Human Rights 2007: 25.

Note 42. Hodgkinson \& Rutherford (1996) 172-73.

Note 43. Hodgkinson \& Rutherford (1996) 173.

Note 44. Terblanche (2004) 109.

Note 45. Terblanche (2004) 101. In $S$ v Ferreira 20042 SACR 454 (SCA), the accused contracted two men to kill her husband. The facts pointed towards sustained severe abuse. The trial court imposed the prescribed life imprisonment but the Supreme Court of Appeal expressed the view that a non-custodial sentence would have sufficed. Also in $S v$ Malgas 20011 SACR 469 (SCA), the appellant was a friend of the deceased's wife. The appellant's youth and the manner in which she was pressured by the wife to kill the deceased, were held to amount to substantial and compelling circumstances justifying a departure from the prescribed life imprisonment. She was sentenced to twenty-five years' imprisonment. In $S v$ Thebus 20022 SACR 566 (SCA), a group of vigilantes decided to take the law into their own hands against suspected drug dealers operating in their township. At one point a suspected drug dealer fired a shot at the motorcade of these vigilantes, and when the vigilantes returned fire, an innocent girl was killed and two other people wounded. The trial court convicted two of the accused of murder and attempted murder, and sentenced them to eight years' imprisonment, fully suspended on condition that they perform community service. On appeal to the Supreme Court of Appeal, the majority found that although substantial and compelling circumstances were indeed present, the trial court's sentence was grossly inadequate. It increased the sentence to fifteen years.

Note 46. Hodgkinson \& Rutherford (1996) 173.

Note 47. Sun Wanhuai (2009) 171.

Note 48. International Federation for Human Rights 2007: 21. Accessed at http://www.ditshwanelo.org.bw/index/current_issues/death_penalty/death\%20penalty520press\%20statement $\% 20$ -\%2018\%20july\%202003.htm

Note 49. Hatchard \& Coldham, chapter 7. Hodgkinson \& Rutherford (1996) 164.

Note 50. Hatchard \& Coldham, chapter 7. Hodgkinson \& Rutherford (1996) 164.

Note 51. Hatchard \& Coldham, chapter 7. Hodgkinson \& Rutherford (1996) 165.

Note 52. Hatchard \& Coldham, chapter 7. Hodgkinson \& Rutherford (1996) 165.

Note 53. Hatchard \& Coldham, chapter 7. Hodgkinson \& Rutherford (1996) 164.

Note 54. Hatchard \& Coldham, chapter 7. Hodgkinson \& Rutheford (1996) 172.

Note 55. Hood (2001) 344.

Note 56. Hood (2001) 344.

Note 57. International Federation on Human Rights (2007) 25.

Note 58. International Federation on Human Rights (2007) 25.

Note 59. International Federation on Human Rights (2007) 26.

Note 60. International Federation on Human Rights (2007) 27.

Note 61. International Federation on Human Rights (2007) 27. 
Note 62. International Federation on Human Rights (2007) 27.

Note 63. International Federation on human Rights (2007) 27.

Note 64. Peter Hodgkinson \& Andrew Rutherford (1996) 171.

Note 65. Hodgkinson \& Rutherford (1996) 172.

Note 66. Hatchard (1994) 926.

Note 67. International Federation for Human Rights (2007) 30.

Note 68. Hodgkinson \& Rutherford (1996) 161. Hatchard \& Coldham, ch. 7.

Note 69. Hodgkinson \& Rutherford (1996) 162.

Note 70. Sun Wanhuai (2009) 167. 